\title{
Some Advances in Synthetic Biomedical Polymers
}

\author{
Xin-De FENG \\ Polymer Division, Department of Chemistry, \\ Peking University, Beijing, China
}

(Received August 20, 1984)

\begin{abstract}
This paper is concerned with some recent advances in synthetic polymers of biomedical potentialities with emphasis on their hemocompatible and bioactive properties. Some multiphase polyurethane with fair blood compatibilities are expected to have a positive impact on cardiovascular devices, further improvement of their thromboresistance was made by surface graft polymerization of hydrogel either on the hard segment with ceric ion initiation or on the soft segment with controlled oxidation to hydroperoxide and then with $\mathrm{Fe}^{++}$or DMT. Several poly(sulfoalkyl methacrylate)s especially with $n=8$ or 10 in $-\mathrm{COO}\left(\mathrm{CH}_{2}\right)_{n} \mathrm{SO}_{3} \mathrm{Na}$ have been synthesized and tested in hemoperfusion process with emphasis on their anticoagulant properties. Some poly(vinyl alcohol) based macroreticular, hydrophilic and spherical carriers were prepared and then functionized to bioactive polymers which were tested in affinity chromatography. A series of aspirin releasing biocompatible polymers and copolymers were synthesized from 2-hydroxyethyl methacrylate (HEMA) or glyceryl methacrylate (GMA) monomers and tested as controlled release polymeric drugs. Biodegradable block copolymers were synthesized from $\varepsilon$-caprolactone and DLlactide with bimetallic $\mu$-oxoalkoxide as catalyst and then tested for controlled release delivery system.
\end{abstract}

KEY WORDS Hemocompatible Grafted Poly(ether-urethane) / Poly(sulfoalkyl methacrylate)s / Biocompatible Aspirin Releasing Polymers / Functionized Macroreticular Spherical Carriers / Biodegradable Block Copolymers / $\varepsilon$-Caprolactone and Lactide /

As a class of biomaterial, synthetic biomedical polymers have made an important contribution to modern health care. In this young but rapidly developing field, quite a lot of fundamental problems remain unsolved, such as how to choose synthetic polymer for particular medical applications. To date, most biomaterials in applications rely on industrial substances that were initially developed in industry for non-medical purposes. Now the tendency has been to synthesize the polymers most suitable to the intended application, i.e., to match the overall properties of the polymers to their end uses. Therefore the development of a better fundamental understanding of the behavior of these polymers can enhance the ability to design new material for the intended application. In order to meet such a demand the relation between the structure and various properties of these synthesized polymers should be studied. Thus a wide range of the test polymers or a spectrum of these polymers with different structures should be synthesized at first. It is expected that a new branch of fundamental research so called molecular tailoring or design of synthetic biomaterial will be emerging. From this point of view, the present paper presents some recent synthetic studies of our laboratories on several important classes of new polymers with emphasis on their hemocompatible and bioactive properties including controlled releasing drug system and biodegradable sustained release matrix.

\section{HEMOCOMPATIBLE POLYMERS}

\section{Segemented Poly (ether-urethane) (PEU)}

Poly(urethane) elastomers are now entering clinical use and are expected to have a positive impact on cardiovascular and vascular repair devices, although results have not been consistent as desired, i.e., sometimes still form some clots on the implants.

For in vivo thromus formation on a polymer 
surface which often rapidly forms an adsorbed protein layers in contact with blood. Lyman et al. ${ }^{1}$ tested a series of polymer material with the results shown in the following table (Table I) and then proposed the selective adsorption mechanism, i.e., surface appears to be nonthrombogenic if it preferentially adsorbs albumin in situ, while globulin or fibrinogen adsorption will cause fibrin and then clot formation.

The above table shows that poly(urethane)s with sufficient long soft segment and micro-phase separation adsorb albumin preferentially and possess good blood compatibilities in comparing with silicone rubber and fluoro-rubber. Imai ${ }^{2}$ pointed out that the materials exhibiting the micro-heterophase structure of some specified dimension are promising in thromboresistance. Okano et al. $^{3}$ studied the block copolymers of 2-hydroxyethyl methacrylatestyrene (PHEMA-PSt) and considered that the microdomain structure with $10^{2} \AA$ order are criti-

Table I. Homocompatibility of various polymers

\begin{tabular}{lccc}
\hline & $\begin{array}{c}\text { \% Relative composition } \\
\text { of adsorbed protein }\end{array}$ & $\begin{array}{c}\text { Platelet } \\
\text { Polymer }\end{array}$ & Albumin \\
\cline { 2 - 3 } & & $\begin{array}{c}\text { Globulin \& } \\
\text { fibrinogen }\end{array}$ & (1 min) \\
\hline Teflon FEP & 30 & 70 & 5.4 \\
Silastic rubber & 70 & 30 & 4.5 \\
PEUU 710 (PPO) & 62 & 38 & 2.5 \\
PEUU 1025 (PPO) & 98 & 2 & 0.2 \\
Biomer & 98 & 2 & 0.2 \\
\hline
\end{tabular}

${ }^{a}$ Fluorinated ethylene-propylene copolymer. cally important and Nakajima ${ }^{4}$ recently proposed further the interaction mechanism with the calculated critical value of domain size of $350 \AA$. We $\mathrm{We}^{5-7}$ have noticed the importance of the size and structure of the hard domain and verified that same reactants but with different reaction processes will give PEU of different chain structures which in turn will give different morphological structures and then different properties with the following results (Table II).

The above results show that process $\mathrm{B}$ will give better microphase separation with small size crystal hard domain. So we suppose that process B would provide the prepolymer with regular structure of methylenediphenylisocyanate-poly(tetramethylene glycol)-methylenediphenylisocyanate (MDIPTMG-MDI), while process A would give a mixture of prepolymers containing not only the above one but also MDI-PTMG-MDI-PTMG-MDI and MDI species which in turn make the chain extension reaction more complex and give hard segment of various compositions.

In selection of a prosthetic material for cardiovascular application, the primary concern of hemocompatibility must be coupled with long fatigue life since the cardiac rate is approximately $40 \times 10^{6}$ cycles per year. Szycher ${ }^{8}$ presented the following data of accelerated flex tests at -20 to $-40^{\circ} \mathrm{F}$ of several candidate poly(urethane)s (Table III). In 1977 they eliminated Adiprene for fabrication diffculties and selected Biomer and Tecoflex HR as the two most promising bladder or diaphragm materials. Since 1980 they ${ }^{9}$ preferred Pellethane 2363$80 \mathrm{~A}$ to Tecoflex HR through comprehensive endurance test.

Table II. Characterization of segmented poly(ether-urethane) ${ }^{\mathrm{a}}$

\begin{tabular}{|c|c|c|c|c|c|}
\hline Extender & $\begin{array}{l}\text { Reaction } \\
\text { process }\end{array}$ & {$[\eta]$} & $\frac{\text { Hard segment }}{\text { Domain form }}$ & $\frac{\text { Size }}{\AA}$ & $\%$ \\
\hline ED & A & 0.86 & Spherical amorphous & 2000 & 32.5 \\
\hline ED & B & 0.71 & Sticklike crystal & $50-100$ & 33.7 \\
\hline $\mathrm{BD}$ & A & 0.77 & Irregular amorphous & 1200 & 34.1 \\
\hline $\mathrm{BD}$ & B & 0.61 & Irregular crystal & 600 & 36.3 \\
\hline
\end{tabular}

a Mole ratio: PTMG: MDI : extender = 1:2:1, poly(tetramethylene glycol) (PTMG), $\mathrm{HO}-\left(\mathrm{CH}_{2} \mathrm{CH}_{2} \mathrm{CH}_{2} \mathrm{CH}_{2} \mathrm{O}\right)_{n} \mathrm{OH}$; methylenediphenylisocyanate (MDI), OCN- $\mathrm{C}_{6} \mathrm{H}_{4}-\mathrm{CH}_{2}-\mathrm{C}_{6} \mathrm{H}_{4}-\mathrm{NCO}$; ethylene-diamine (ED), $\mathrm{NH}_{2} \mathrm{CH}_{2} \mathrm{CH}_{2} \mathrm{NH}_{2}$; butylenediamine (BD), $\mathrm{HOCH}_{2} \mathrm{CH}_{2} \mathrm{CH}_{2} \mathrm{CH}_{2} \mathrm{OH}$.

Process A, adding MDI to PTMG, then extender. Process B, adding PTMG to MDI, then extender. 
Surface Modification of PEU

Although the hemocompatible properties of some segmented PEU are fair further improvements can be achieved with surface graft copolymerization of hydrogels, which are useful in a variety of temporary as well as intermediates term applications, including coatings of catheters, shunts, cannulae, oxygenator and artificial kidney membrane, encapsulants in hemodialysis and cardiac-assist devices. Halpern ${ }^{10}$ made the first chemical grafting of polyacrylamide hydrogel to the segmented PEU with poly(propylene oxide) (PPO) as soft segment by ceric ion initiation with the following results

Table III. Flex test of poly(urethane)s

\begin{tabular}{lrc}
\hline \multirow{2}{*}{ Specimen } & \multicolumn{2}{c}{ Cycles to failure } \\
\cline { 2 - 3 } & \multicolumn{1}{c}{$(1977)$} & $(1980)$ \\
\hline Pellethane & 3000 & $70 \%$ after $4 y^{9}$ \\
Avcothane & 100,000 & $100 \%$ after $3 y, 352 \times 10^{6}$ \\
Biomer & $1,500,000$ & $70 \%$ after $5 y^{9}, 320 \times 10^{6}$ \\
Adiprene & $1,700,000$ & \\
Tecoflex HR & $3,000,000(\sim 0 \%) 2-3 y^{9}, 100 \times 10^{6}$ \\
\hline
\end{tabular}

(Table IV).

But some discrepancy between in vivo and in vitro results was ascribed to the state-of-art in testing blood compatibility and the specimens themselves. So $\mathrm{we}^{11}$ investigated the similar graft copolymerization but with different soft segment (PTMG). The grafted substances in film form become opaque with much higher percent of water absorption ( $30-40 \%)$ and salient pictures from scanning electron microscope photogram which clearly show the grafts of macrochains on the surface of the films. Through varieties of model compounds of PEU as shown in the following scheme, we then studied the reaction mechanism of this graft copolymeriation with the results in term of relative rate of polymerization (Figure 1 and Table V).

The above results show that it is the acetanilide $\mathrm{C}_{6} \mathrm{H}_{5} \mathrm{NHCOCH}_{3}$ structure but not the $N$-alkyl amide structure such as $N$-methyl benzoyl amide (NMA) responsible for graft copolymerization and the main site of grafting will be the $\alpha-\mathrm{H}$ of the $\mathrm{N}$ atom of acetanilide. The relative rates of polymerization $\left(R_{\mathrm{r}}\right)$ of $\mathrm{C}_{6} \mathrm{H}_{5} \mathrm{~N}\left(\mathrm{CH}_{3}\right) \mathrm{COCH}_{3}$ will drop to 1.2 as the $\alpha-\mathrm{H}$ is substituted. So we propose the reaction

Table IV. Homocompatibility of grafted poly(urethane)s ${ }^{a}$

\begin{tabular}{lccccccc}
\hline & \multicolumn{3}{c}{ Protein adsorbed } & & \multicolumn{2}{c}{ Leonard spinning disk test $\mathrm{t}^{\mathrm{b}}$} \\
\cline { 2 - 4 } \cline { 6 - 8 } Specimen & Albumin & Fibrinogen & Globulin & & Fibrinogen & Globulin & $\begin{array}{c}\text { Platelet } \\
\left(\mathrm{Cell} / 90 \mu \mathrm{m}^{2}\right)\end{array}$ \\
\hline PEU & 0.58 & 0.92 & 0.93 & & 2.2 & 1.5 & 11.0 \\
PEU graft PAM \& C.L. & 0.19 & 0.18 & 0.29 & & - & - & - \\
PEU graft PAM only & 0.97 & 0.11 & 0.09 & & 0.8 & 0.4 & 0.05 \\
\hline
\end{tabular}

a PEU, 3-1000/425(70/30)-1-x, SRI; PAM, poly(acrylamide); C.L., crosslinking.

b 4 min.

PEU: $\stackrel{\text { II }}{\mathrm{C}}-\mathrm{NH}-\mathrm{C}_{6} \mathrm{H}_{4}-\mathrm{CH}_{2}-\mathrm{C}_{6} \mathrm{H}_{4}-\mathrm{NHCO}\left(\mathrm{CH}_{2} \mathrm{CH}_{2} \mathrm{CH}_{2} \mathrm{CH}_{2} \mathrm{O}{ }_{7} \stackrel{\mathrm{I}}{\mathrm{C}} \underset{\mathrm{NH}}{\mathrm{O}}-\mathrm{C}_{6} \mathrm{H}_{4}-\mathrm{CH}_{2}-\mathrm{C}_{6} \mathrm{H}_{4}-\mathrm{NHCNHCH}_{2} \mathrm{CH}_{2} \mathrm{NH}-\right.$

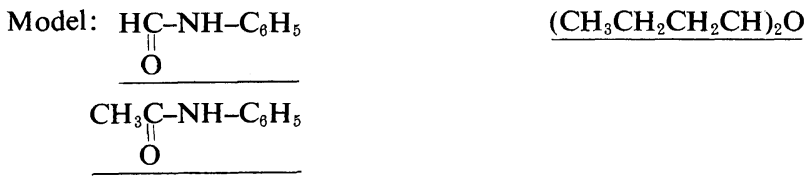

End groups: $-\mathrm{CH}_{2} \mathrm{CH}_{2} \mathrm{NH}_{2},-\mathrm{CH}_{2} \mathrm{CH}_{2} \mathrm{CH}_{2} \mathrm{CH}_{2} \mathrm{OH}$ $\underline{\mathrm{CH}_{3} \mathrm{CH}_{2} \mathrm{CH}_{2} \mathrm{NH}_{2}} \quad \underline{\mathrm{CH}_{3} \mathrm{CH}_{2} \mathrm{CH}_{2} \mathrm{CH}_{2} \mathrm{OH}}$

Figure 1. The model compounds of different functional groups of PEU. 
Table V. Relative rates $\left(R_{\mathrm{r}}\right)$ of polymerization

\begin{tabular}{|c|c|}
\hline Model compound & $R_{\mathrm{r}}$ \\
\hline Control & 1.00 \\
\hline $\mathrm{C}_{6} \mathrm{H}_{5} \mathrm{NHCOCH}_{3}$ (AA) & 2.64 \\
\hline $\mathrm{C}_{6} \mathrm{H}_{5} \mathrm{NHCHO}(\mathrm{FA})$ & $\underline{2.44}$ \\
\hline$n-\mathrm{BuOH}$ & 1.21 \\
\hline$n-\mathrm{PrNH}_{2}$ & 1.18 \\
\hline $\mathrm{HCOOC}_{2} \mathrm{H}_{5}$ & 1.12 \\
\hline $\mathrm{CH}_{3} \mathrm{CONHR}$ & 1.11 \\
\hline $\mathrm{NH}_{2} \mathrm{CONH}_{2}$ & 1.03 \\
\hline$(n-\mathrm{Bu})_{2} \mathrm{O}$ & 1.01 \\
\hline $\mathrm{C}_{6} \mathrm{H}_{13} \mathrm{NHCOCH}_{3}$ & 1.04 \\
\hline $\mathrm{C}_{4} \mathrm{H}_{9} \mathrm{NHCOCH}_{3}$ & 1.11 \\
\hline $\mathrm{HCONMe}_{2}$ & 1.01 \\
\hline $\mathrm{HCONH}_{2}$ & $\sim 1$ \\
\hline$p-\mathrm{CH}_{3} \mathrm{C}_{6} \mathrm{H}_{4} \mathrm{NHCOCH}_{3}$ & 4.5 \\
\hline$p-\mathrm{ClC}_{6} \mathrm{H}_{4} \mathrm{NHCOCH}_{3}$ & $\overline{1.9}$ \\
\hline $\mathrm{C}_{6} \mathrm{H}_{5} \mathrm{~N}\left(\mathrm{CH}_{3}\right) \mathrm{COCH}_{3}$ & 1.2 \\
\hline $\mathrm{C}_{6} \mathrm{H}_{5} \mathrm{CONHCH}_{3}$ (MMA) & 1.09 \\
\hline MDI-ED & 2.01 \\
\hline MDI-BD & 1.67 \\
\hline PTMG (1000-2000) & $1.04-1.06$ \\
\hline
\end{tabular}

mechanism of graft copolymerization of vinyl monomer onto the PEU backbone with ceric ion initiation as follows:

$$
\begin{aligned}
& \mathrm{Ce}^{+4}+\mathrm{H}_{2} \mathrm{O} \longrightarrow \mathrm{Ce}(\mathrm{OH})^{+3}+\mathrm{H}^{+} \\
& \text {- }
\end{aligned}
$$

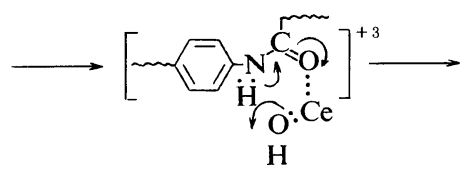

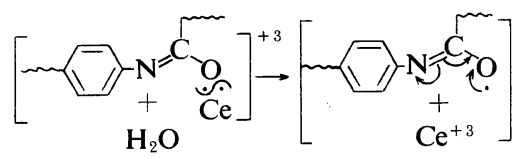

$$
\begin{aligned}
& \Longrightarrow \stackrel{\mathrm{O}}{\mathrm{II}} \sim(\mathrm{P} \cdot \mathrm{C} \\
& \mathrm{P} \cdot+\stackrel{k_{\mathrm{i}}}{\longrightarrow} \mathrm{PM} \text {. } \\
& \mathrm{PM} \cdot+\mathrm{M} \stackrel{k_{\mathrm{p}}}{\longrightarrow} \mathrm{PM}_{n} \text {. } \\
& \mathrm{PM}_{n} \cdot+\mathrm{Ce}^{+4} \stackrel{k_{\mathrm{t}}}{\longrightarrow} \mathrm{PM}_{n}+\mathrm{Ce}^{+3}+\mathrm{H}^{+}
\end{aligned}
$$

It is reasonable to suggest that the ceric ion graft copolymerization onto PEU will be selective, i.e., mainly on the hard segments of PEU.
A new graft copolymerization method ${ }^{12}$ on PEU was performed through controlled oxidation with $30 \% \mathrm{H}_{2} \mathrm{O}_{2}$ at room temperature for around $22 \mathrm{~h}$. The oxidation could be controlled on the $\alpha-\mathrm{H}$ atom of ether linkage to form the corresponding hydroperoxide $(-\mathrm{OOH})$ without further. Graft copolymerization will proceed by treating with $\mathrm{Fe}^{++}$ through the formed macro alkoxy radical without homopolymerization as follows:
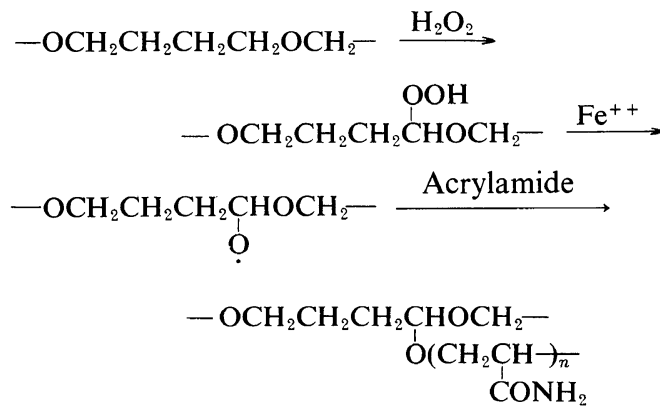

In the case of Hytrel it will be oxidized much easier so only $11 \mathrm{~h}^{11}$ was enough to oxidize to the same stage as in the case of above PEU. It is also reasonable to suggest that the controlled oxidation method of graft copolymerization onto PEU will be also selective, i.e., mainly on the soft segments of PEU.

Recently Matsuda et al. ${ }^{13}$ pointed out from ESCA measurement that the surface layer (air side) of segmented poly(urethane) (SPU) is rich in soft segment domains and further elucidated that platelet adhesion and thrombin adsorption are less with soft segment model polymers than with the hard segment model polymers as follows (Table VI).

Now we present the data of graft copolymerization on PEU either by ceric ion or by oxidation method as follows (Tables VII and VIII). ${ }^{11}$

The above results of graft amount and related properties show that i) both $\mathrm{Ce}^{+4}$ method and oxidation method are effective to graft AAM or HEMA onto PEU or Hytrel ii) $\mathrm{Ce}^{+4}$ method is more effective for PEU than for Hytrel iii) $\mathrm{H}_{2} \mathrm{O}_{2}$ oxidation is more feasible on Hytrel than PEU and oxidation method is good for higher grafting amount without degradation of the film, i.e., mainly surface graft iv) oxidation method with $\mathrm{Fe}^{++}$will give pure graft copolymer without homopolymer of hydrogel v) oxidation method of graft copolymerization can be followed by $\mathrm{Ce}^{+4}$ method of graft 
Table VI. Hemocompatibility of soft/hard segment analogues of SPU

\begin{tabular}{lcc}
\hline Polymer surface & $\begin{array}{c}\text { Thrombin } \\
\text { adsorption }\end{array}$ & $\begin{array}{c}\text { Platelet } \\
\text { adsorption }\end{array}$ \\
\hline $\begin{array}{l}\text { Glass (control) } \\
\text { Hard segment analogues }\end{array}$ & 1.00 & 1.00 \\
$\quad$ Poly(urethane) & 0.62 & 0.7 \\
$\quad$ Polyurea & 0.67 & 0.7 \\
Soft segment analogues & & \\
PTMG & 0.09 & 0.2 \\
PPO & 0.09 & 0.3 \\
PEO & 0.05 & 0.1 \\
Poly(dimethylsiloxane) & 0.21 & 0.4 \\
\hline
\end{tabular}

copolymerization to give some additive results as follows (Table IX):

The above results of the contact angle $(\theta)$ and the relative clotting time $(\mathrm{Cr})$ show that i) thromboresistance of PEU will be doubled either by $\mathrm{Ce}^{+4}$ or oxidation method of acrylamide (AAM) graft, while HEMA is somewhat less effective ii) thromboresistance of Hytrel itself is unexpected high even higher than the grafted PEU and it will still increase about $30 \%$ through graft copolymerization in which oxidation method is much easier to be performed. We would like to suggest that the grafted Hytrel may appear as some new potential thromboresistant biomedical polymeric material with the following structure:

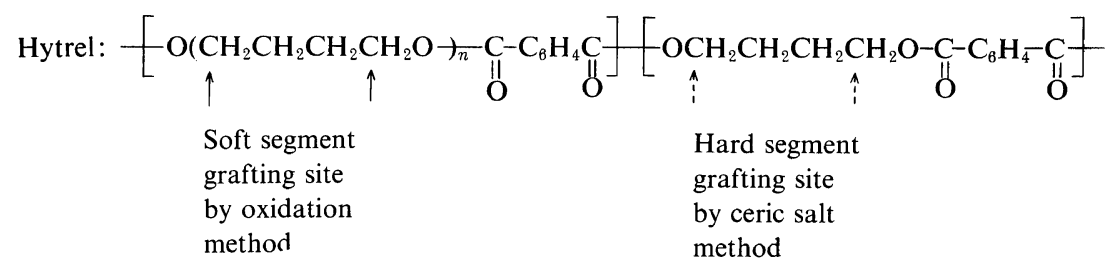

Table VII. Graft copolymerization onto PEU

\begin{tabular}{|c|c|c|c|c|}
\hline Code & I & II & III & IV \\
\hline Graft monomer & AAM & HEMA & AAM & HEMA \\
\hline Graft method & $\mathrm{Ce}^{+4}$ & $\mathrm{Ce}^{+4}$ & $\mathrm{H}_{2} \mathrm{O}_{2}$ & $\mathrm{H}_{2} \mathrm{O}_{2}$ \\
\hline Graft time/h & $1.0 \quad 1.0$ & $3.3 \quad 3.3$ & $\begin{array}{ll}1.8 & 1.8\end{array}$ & $2.8 \quad 2.8$ \\
\hline Graft amount $/ \mathrm{mg} \mathrm{cm}^{-2}$ & $2.77 \quad 2.55$ & $2.50 \quad 2.52$ & $0.78 \quad 0.80$ & $11.7 \quad 13.0$ \\
\hline $\mathrm{H}_{2} \mathrm{O}$ adsorbed $/ \mathrm{mg} \mathrm{cm}^{-2}$ & $15.3 \quad 13.8$ & $2.97 \quad 3.38$ & $7.09 \quad 7.80$ & $13.3 \quad 13.7$ \\
\hline Contact angle, $\theta$ & $37.8 \pm 9.0$ & $43.6 \pm 10.0$ & $38.3 \pm 5.8$ & $45.8 \pm 3.8$ \\
\hline Relative recalcification time $\left(C_{\mathrm{r}}\right)$ & 2.33 & 1.98 & 2.22 & 1.54 \\
\hline
\end{tabular}

${ }^{\mathrm{a}}\left[\mathrm{Ce}^{+4}\right]=5.0 \times 10^{-3} \mathrm{M} ;\left[\mathrm{Fe}^{++}\right]=8.0 \times 10^{-3} \mathrm{M},[\mathrm{monomer}]=2.0 \mathrm{M}$, room temp. control: glass, $C_{\mathrm{r}}=1.00 ; \mathrm{PEU}$, $\theta=70.0 \pm 6.0 ; C_{\mathrm{r}}=1.50$

Table VIII. Graft copolymerization onto Hytrel ${ }^{\mathrm{a}}$

\begin{tabular}{|c|c|c|c|c|}
\hline Code & I & II & III & IV \\
\hline Graft monomer & AAM & HEMA & AAM & HEMA \\
\hline Graft method & $\mathrm{Ce}^{+4}$ & $\mathrm{Ce}^{+4}$ & $\mathrm{H}_{2} \mathrm{O}_{2}$ & $\mathrm{H}_{2} \mathrm{O}_{2}$ \\
\hline Graft time/h & $26.4 \quad 26.4$ & $5.2 \quad 5.2$ & $4.0 \quad 4.0$ & $11.4 \quad 11.4$ \\
\hline Graft amount $/ \mathrm{mg} \mathrm{cm}^{-2}$ & $4.04 \quad 4.31$ & $0.64 \quad 0.70$ & $3.28 \quad 3.51$ & $36.7 \quad 32.7$ \\
\hline $\mathrm{H}_{2} \mathrm{O}$ adsorbed $/ \mathrm{mg} \mathrm{cm}^{-2}$ & $5.03 \quad 6.03$ & $1.80 \quad 1.90$ & $21.5 \quad 22.6$ & $20.7 \quad 18.7$ \\
\hline Contact angle, $\theta$ & $34.7 \pm 12.0$ & $39.6 \pm 9.0$ & $35.5 \pm 5.0$ & $36.5 \pm 6.0$ \\
\hline Relative recalcification time $\left(C_{\mathrm{r}}\right)$ & 4.09 & 3.70 & 3.98 & \\
\hline
\end{tabular}

${ }^{\mathrm{a}}\left[\mathrm{Ce}^{+4}\right]=5.0 \times 10^{-3} \mathrm{M} ;\left[\mathrm{Fe}^{++}\right]=8.0 \times 10^{-3} \mathrm{M},[$ monomer $]=2.0 \mathrm{M}$, room temp. control: glass, $C_{\mathrm{r}}=1.00 ;$ Hytrel, $\theta=62.0 \pm 6.0 ; C_{\mathrm{r}}=3.25$. 
X-D. FENG

Table IX. Graft copolymerization onto PEU

\begin{tabular}{|c|c|c|c|c|c|}
\hline \multirow{2}{*}{ Code } & \multicolumn{2}{|c|}{ Oxidation method } & \multirow{2}{*}{$\mathrm{Ce}^{++}$method } & \multicolumn{2}{|c|}{ Total result } \\
\hline & Graft amount ${ }^{b}$ & $\mathrm{H}_{2} \mathrm{O}$ absorption & & Graft amount & $\mathrm{H}_{2} \mathrm{O}$ absorption \\
\hline S-014 & 4.07 & 15.8 & 12.8 & 16.9 & 50.1 \\
\hline S-014 & 1.76 & 10.7 & 9.21 & 11.0 & 29.1 \\
\hline \multicolumn{6}{|c|}{ 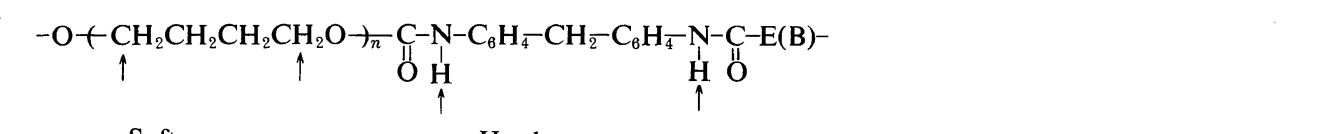 } \\
\hline & $\begin{array}{l}\text { ft segment } \\
\text { ffting }\end{array}$ & $\begin{array}{l}\text { Hard segr } \\
\text { grafting si }\end{array}$ & & & \\
\hline
\end{tabular}

Table $\mathbf{X}$. The heparin retarded time test

\begin{tabular}{|c|c|c|c|c|c|}
\hline \multirow{3}{*}{$\frac{\text { Clotting time }}{\min }$} & \multirow{3}{*}{$\frac{\text { Heparin concn }}{\mathrm{mg} \mathrm{ml}^{-1}}$} & \multicolumn{2}{|c|}{ PSSHMA } & \multicolumn{2}{|c|}{ PSSEMA } \\
\hline & & Concn & Activity ratio & Conen & Activity ratio \\
\hline & & $\overline{\mathrm{mg} \mathrm{ml}^{-1}}$ & $\%$ & $\overline{\mathrm{mg} \mathrm{ml}^{-1}}$ & $\%$ \\
\hline 5 & 0.0051 & 0.14 & 3.6 & 0.46 & 1.1 \\
\hline 7 & 0.0073 & 0.21 & 3.5 & 1.03 & 0.7 \\
\hline 10 & 0.0096 & 0.28 & 3.5 & 1.63 & 0.6 \\
\hline
\end{tabular}

\section{Poly(sulfoalkyl methacrylate)s and Their Antico- agulant Activities}

Heparin is widely distributed in mammalian tissues and fluids of lung, liver, spleen or muscle. It was proved to be highly sulfated anionic polysaccharide with molecular weight up to 20,000 and used in medicine as an effective anticoagulant for blood clotting. Although heparinized biomaterials prepared by ionic bonding through the formation of a complex with quaternary ammonium salt exhibit good antithrombogenicity, yet heparin in such form will leach out from the materials gradually into blood stream. So covalently bonded heparin through ordinary immobilization methods were prepared but they usually show little antithrombogenicity. On the other hand quite a number of synthetic polymers having sulfonate or sulfate ions were prepared and examined. Among them several poly(sulfoalkyl methacrylate)s with longer length of alkylene groups were synthesized in our laboratory ${ }^{14}$ as follows:

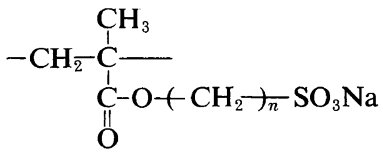

$n=2$ poly(sodium sulfoethyl methacrylate) (PSSEMA)

$n=6$ poly(sodium sulfohexyl methacrylate) (PSSHMA)

$n=8$ poly(sodium sulfooctyl methacrylate) (PSSOMA)

The heparin retarded time tests were performed with the following results (Table $\mathrm{X}$ ).

The above results show that the anticoagulant activity of PSSHMA is about $3 \%$ of heparin and $>3$ times greater than that of PSSEMA. This may be ascribed to the spacer effect, i.e., sufficient long length of the alkylene group from the backbone of the polymer main chain will make the $\mathrm{SO}_{3}$ group more feasible.

For purpose of further comparison, ${ }^{15}$ the heparin retarded time tests of poly(sodium vinyl sulfonate) (PSVS), PSSEMA, PSSHMA, and PSSOMA were carried out simultaneously. The decreasing order of clotting time was observed as: 
PSSOMA $>$ PSSHMA $>$ PSSEMA $>$ PSVS

The anticoagulant index curves were obtained with $\log 1 / c$ (concn of sample) as abscissa and $t / t_{0}$ as ordinate where $t$ and $t_{0}$ represent the clotting time with and without anticoagulant respectively. When the concentration was $0.4 \mathrm{mg} \mathrm{ml}^{-1}$, and $\log 1 / c$ was 0.4 , the anticoagulant index of the above polymers were $18.5,12.7,7.6$, and 2.3 respectively.

The spacer effect became more evident from following data of plasma recalcification time test, i.e., copolymers of HEMA and sulfoakyl methacrylate monomer in $4: 1$ feed ratio were used to coat the inner walls of test tubes (Table XI).

The sodium sulfooctyl methacrylate (SSOMA) copolymer appears to be very promising in its anticoagulant activity, so the higher members of poly(sulfoalkyl metacrylate) or its copolymers may come out as a potential class of biomedical polymer with superior antithrombogenicity.

\section{Polyelectrolyte Complexes as Hemocompatible Polymers}

Nakajima et al. ${ }^{16}$ used slightly sulfated poly(vinyl alcohol) (PVA) as the polyanion (PA) and

Table XI. Plasma recalcification test

\begin{tabular}{cc}
\hline Copolymer & Recalcification time \\
\hline PHEMA-SSOMA & $5 \mathrm{~h}$ \\
PHEMA-SSHMA & $100 \mathrm{~s}$ \\
PHEMA-SSEMA & $53 \mathrm{~s}$ \\
\hline
\end{tabular}

Table XII. Plasma recalcification time of PVA derivatives

\begin{tabular}{|c|c|c|c|c|}
\hline \multirow{3}{*}{ PIC } & \multicolumn{2}{|c|}{ Charge density } & \multirow{2}{*}{$\begin{array}{l}\text { Recalci- } \\
\text { fication } \\
\text { time }\end{array}$} & \multirow{3}{*}{$\begin{array}{c}C_{\mathrm{r}} \\
\text { (Relative } \\
\text { time) }\end{array}$} \\
\hline & \multicolumn{2}{|c|}{$\mathrm{mol} \%$} & & \\
\hline & PC & PA & s & \\
\hline $\mathrm{PCI}_{1}-\mathrm{PAII}_{2}$ & 35 & 31 & 131 & 1.07 \\
\hline $\mathrm{PCI}_{1}$-PAIII & 35 & 34 & 125 & 1.02 \\
\hline $\mathrm{PCII}_{2}-\mathrm{PAII}_{2}$ & 32 & 31 & 137 & 1.12 \\
\hline $\mathrm{PCII}_{2}$-PAIII & 36 & 34 & 141 & 1.16 \\
\hline $\mathrm{PCII}_{5}-\mathrm{PAII}_{2}$ & 64 & 31 & 287 & 2.50 \\
\hline $\mathrm{PCII}_{5}-\mathrm{PAII}_{3}$ & 64 & 34 & 225 & 1.80 \\
\hline Glass (control) & & & 122 & 1.00 \\
\hline
\end{tabular}

Polymer J., Vol. 17, No. 1, 1985 slightly aminoacetylated PVA as the polycation (PC) to form polyion complex (PIC) with glutaraldehyde as crosslinking agent. Such PIC possesses good antithrombogenicity. Tsuruta et al. ${ }^{17}$ used poly(styrene sulfonate) and poly(vinyl phenyl ethyl triethyl ammonium bromide) as polyion complex and also showed its good thromboresistance as stated. Recently we have synthesized the following polycations and polyanions from poly(vinyl alcohol) ${ }^{18}$ i.e.,

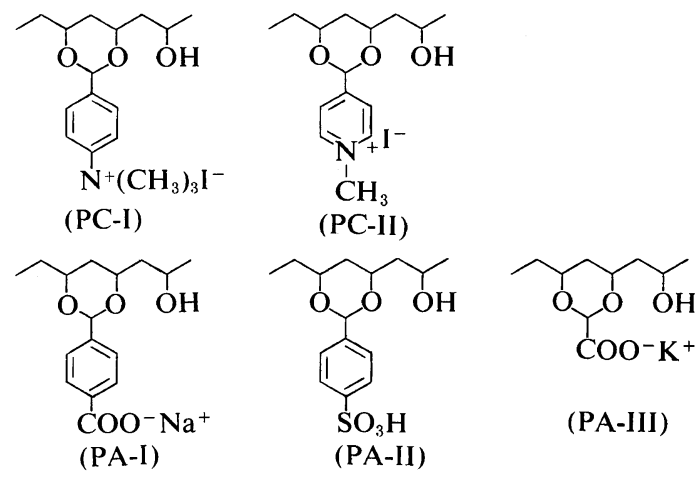

The plasma recalcification time of the above PVA derivatives are as follows (Table XII):

The above results show that all PIC with charge densities less than $40 \%$ would not improve their thromboresistance unless $\mathrm{mol} \%$ of PC increases to 64 . The charge density of $64 / 31$ will still show much better hemocompatible properties than that of 64/34. Such a PIC will give the plasma recalcification time similar to that of the grafted PEU samples.

\section{BIOACTIVE POLYMERS}

Macroreticular, Hydrophilic, and Spherical Carrier ${ }^{18}$

Through one step process macroreticular, hydrophilic, but water insoluble carrier in spherical form were prepared successfully from PVA with terephthalic aldehyde (TPA) as crosslinking agent and tetraethylene glycol (TEG) as pore forming agent. The granular size can be regulated by the concentration of PVA, the oil $/ \mathrm{H}_{2} \mathrm{O}$ ratio and stirring rate and rather narrow distribution in granularity can be obtained. For example (Table XIII):

The bioactive polymers were prepared through functionation in which carboxylic acid group on different arms with aldehyde as other end group were introduced at first by reacting with the macro- 
reticular carrier. Then the corresponding bioactive esters were synthesized through $\mathrm{N}$-hydroxyl succinimide (NHS) and dicyclohexyl carbodiimide (DCCI). Different immunoadsorbents were prepared by immobilization of CHOM and their activities toward trypsin were tested with the following results (Table XIV):

The above results show that the flexible arms are much better than the rigid ones in this case. So such macroreticular and hydrophilic bead carrier can be used easily in affinity chromatography with rather promising results.

\section{Biocompatible Acrylic Polymers Having Aspirin Moieties $^{19}$}

Recently the ordinary analgesic and antipyretic drug Aspirin (acetyl salicylic acid, ASA) was discovered to display some anticoagulation effect of blood platelet. Several new polymers have been synthesized and examined for polymeric drug from the following monomers:

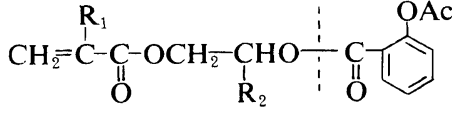

$$
\begin{aligned}
& \begin{array}{ccc}
\mathrm{R}_{1} & \mathrm{R}_{2} & \text { Monomer } \\
\hline \mathrm{CH}_{3} & \mathrm{H} & \text { HEMA-ASA } \\
\mathrm{CH}_{3} & \mathrm{CH}_{3} & \text { HPMA-ASA }
\end{array} \\
& \mathrm{H} H \text { HEA-ASA }
\end{aligned}
$$

\begin{tabular}{|c|c|c|}
\hline \multirow{2}{*}{$\frac{\text { Formula }}{\text { PVA concn } 8 \%}$} & \multicolumn{2}{|c|}{ Properties } \\
\hline & $\begin{array}{l}\text { Specific surface } \\
\text { area }\end{array}$ & $7.3 \mathrm{~m}^{2} \mathrm{~g}^{-1}$ \\
\hline C.L. agent $8 \%$ & Pore volume & $1.16 \mathrm{~cm}^{2} \mathrm{~g}^{-1}$ \\
\hline TEG $\quad 20 \%$ & Pore size & $4000 \AA$ \\
\hline Stirring $200 \mathrm{rpm}$ & Granular size & $50-70 \mu \mathrm{m}$ \\
\hline $\mathrm{Oil} / \mathrm{H}_{2} \mathrm{O} \quad 2.5$ & & \\
\hline Temp $\quad 60^{\circ} \mathrm{C}$ & & \\
\hline
\end{tabular}

Table XIII. Formula and properties of a carrier

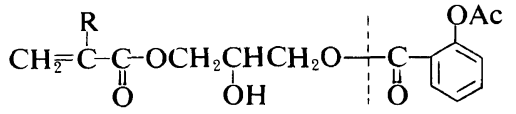

$$
\begin{aligned}
& \text { R Monomer } \\
& \mathrm{CH}_{3} \text { glyceryl methacrylate (GMA)-ASA } \\
& \mathrm{H} \text { glyceryl acrylate (GAA)-ASA }
\end{aligned}
$$

Through homogeneous hydrolysis in acid medium $^{20}$ all the above mentioned polymers would release aspirin (ASA) and salicyclic acid (SA) in the ratio $\mathrm{ASA} / \mathrm{SA} \geqslant 2$ (see Figure 2). In case of alkaline medium, the ratio will be about $\geqslant 1$ (see Figure 3).

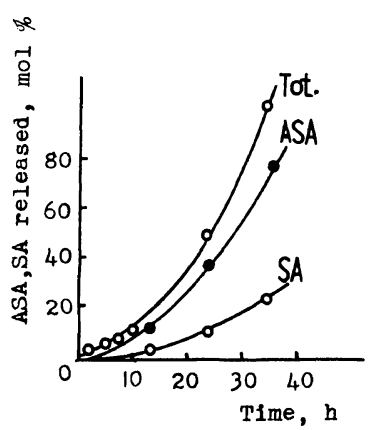

Figure 2. Homogeneous hydrolysis of poly(HEMAASA) in dioxane/ $\mathrm{HCl}$ aqueous solution $(9 / 1, \mathrm{v} / \mathrm{v})$ medium. poly(HEMA-ASA): $1.7 \times 10^{-2}\left(\mathrm{~mol} \mathrm{l}^{-1}\right) \mathrm{pH}=$ $1.25,60^{\circ} \mathrm{C}$.

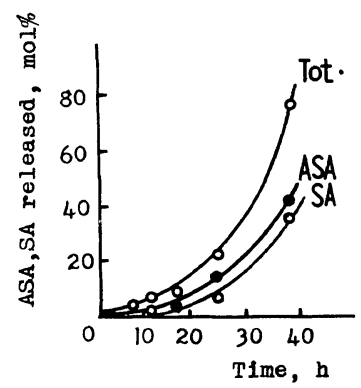

Figure 3. Homogeneous hydrolysis of poly(HEMAASA) in dioxane/ $\mathrm{NaOH}$ aqueous solution $(9 / 1, \mathrm{v} / \mathrm{v})$ medium. Poly(HEMA-ASA): $1.7 \times 10^{-2}\left(\mathrm{~mol} 1^{-1}\right)$ $\mathrm{pH}=7.75,60^{\circ} \mathrm{C}$.

Table XIV. Activities of different immunoadsorbents

\begin{tabular}{cccc}
\hline Arm & $\mathrm{OHC}-\mathrm{COOH}$ & $\mathrm{OHC}-\mathrm{COOH}$ & $\mathrm{OHC}-\mathrm{CH}_{2} \mathrm{CH}_{2} \mathrm{COOH}^{-}$ \\
\hline Meq./10 ml carrier & 4.05 & 0.65 & 0.12 \\
Coupling amount mg/Meq. $\mathrm{COOH}$ & 8 & 104 & 268 \\
Relative activity BAEE unit $\mathrm{mg}^{-1}$ & 2000 & 4000 & 4000 \\
\hline
\end{tabular}




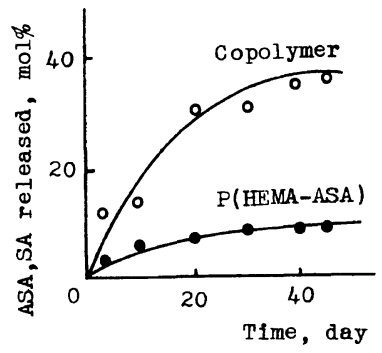

Figure 4. Hydrolysis of poly(HEMA-ASA) and its copolymer in dioxane- $\mathrm{H}_{2} \mathrm{O} .37^{\circ} \mathrm{C}, \mathrm{pH}=1.20$.

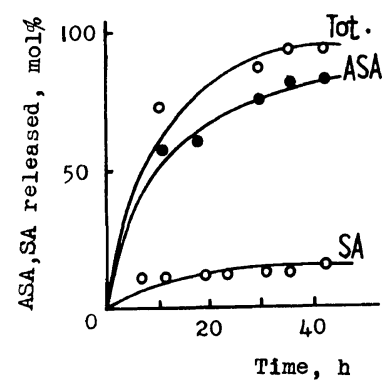

Figure 5. Hydrolysis of poly(HEMA-ASA-co-MA $(69.6 / 30.4)$ in dioxane- $\mathrm{H}_{2} \mathrm{O} .60^{\circ} \mathrm{C}, \mathrm{pH}=7.70$.

The rate of hydrolysis would drop to $1 / 6$ as the temperature decreases from 60 to $37^{\circ} \mathrm{C}$.

Through heterogeneous hydrolysis they would release also mainly aspirin but with much lower rate, i.e., they would last for two years or so. All of the above facts show that hydrolysis usually occurred mainly at the linkage of the carboxy group on the benzene ring moiety as indicated by the dotted line in the above structures of monomers.

We have also synthesized some copolymers of HEMA-ASA with methacrylic acid (MA) ${ }^{21}$ and observed that the presence of MA units in the copolymer will enhance its hydrolysis quite a lot, such as 4 times the rate of homopolymer (see Figure 4). This may be ascribed to the neighboring group effect, i.e., the carboxylate group will assist the hydrolysis as following:<smiles>CCC(C)(CC(C)C)C(=O)OCC(=O)c1ccccc1OCC(C)C</smiles>

Besides, the ratio of the released ASA/SA in alkaline medium of the copolymer increases even to around 6 for the copolymer with 30.1\% MA (see Figure 5) while the value of ASA/SA ratio for the homopolymer is only around 1, i.e., copolymers will favor the liberation of aspirin. The above results suggested that these new copolymers may become some potential candidates of the controlled release biocompatible polymeric drugs to liberate mainly aspirin through prolonged in vivo hydrolysis.

\section{Biodegradable Block Copolymer and Controlled Release System}

Development of biodegradable polymeric materials has been one of the major advances in biomedical material research. The advantage is that it eliminates the need for device removal following use. So it is very useful for constructing short time implant devices. Silicone rubber (Silastic) is popular material for controlled release drug delivery systems in clinical uses but it suffers from their nonbiodegradabilities. It is well-known that poly(caprolactone) (PCL) possesses excellent permeability but poor biodegradability while poly(lactide) (PLA) just the reverse way. It was hoping to make a compromise by random copolymerization of them but the results show that very fast degradation is always obtained even permeability can be regulated. $\mathrm{We}^{22}$ have synthesized the diblock copolymers of PCL and PLA with different segment lengths by bimetallic $\mu$-oxoalkoxide catalyst $\quad\left[\left(n-\mathrm{C}_{4} \mathrm{H}_{9} \mathrm{O}\right)_{2} \mathrm{AlO}\right]_{2} \mathrm{Zn}$ (Teyssie's catalyst) through ring opening polymerization successfully as follows:

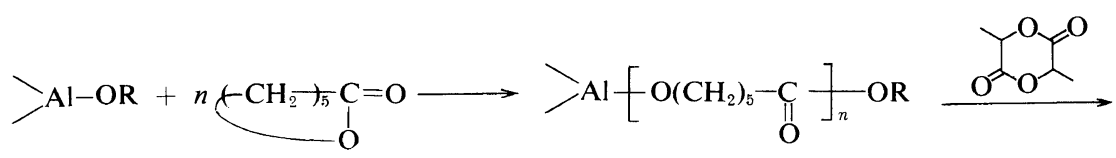

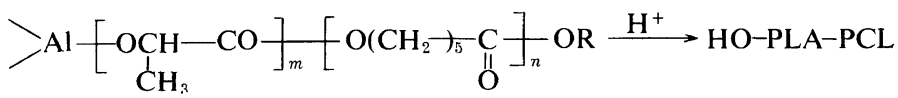


X-D. FENG

Table XV. Physical and mechanical properties of PCL-PLA

\begin{tabular}{|c|c|c|c|c|c|c|}
\hline \multirow{2}{*}{ Code } & $\mathrm{CL} / \mathrm{LA}^{\mathrm{a}}$ & \multirow{2}{*}{$M_{n} \times 10^{-4}$} & \multirow{2}{*}{$M_{\mathrm{PCL}} / M_{\mathrm{PLA}}{ }^{\mathrm{b}}$} & \multirow{2}{*}{$\frac{\mathrm{mp}}{{ }^{\circ} \mathrm{C}}$} & \multirow{2}{*}{$\frac{\text { Tensile strength }}{\mathrm{kg} \mathrm{cm}^{-2}}$} & \multirow{2}{*}{$M_{w} / M_{r}$} \\
\hline & $\mathrm{mol}$ & & & & & \\
\hline $12-03$ & $100 / 0$ & 4.5 & $45000 / 0$ & 63 & 273 & 1.12 \\
\hline $12-05$ & $88 / 12$ & 4.0 & $34000 / 6000$ & 65 & 229 & 1.09 \\
\hline $12-04$ & $72 / 28$ & 3.9 & $26000 / 13000$ & 64 & 220 & 1.05 \\
\hline $6-05$ & $65 / 35$ & 3.2 & $20000 / 12000$ & 66 & 202 & 1.14 \\
\hline $12-06$ & $0 / 100$ & 1.3 & $0 / 13000$ & - & 220 & - \\
\hline
\end{tabular}

a Determined by ${ }^{1} \mathrm{H}$ NMR.

b Calculated from $M_{n}$ of block copolymers and CL/LA.

Table XVI. Degradation of PCL-PLA

\begin{tabular}{rrrc}
\hline $\begin{array}{c}\text { Polymer } \\
\text { No. }\end{array}$ & LA & $\begin{array}{c}\text { Cegradated } \\
\% / 70 \text { days }\end{array}$ & $\begin{array}{c}\text { Completely } \\
\text { degradated } \\
\text { time }\end{array}$ \\
\cline { 2 - 2 } & $\mathrm{mol}^{\circ}$ & & month $^{\mathrm{a}}$ \\
\hline $12-03$ & 0 & 20 & 33 \\
$12-05$ & 12 & 50 & 12 \\
$12-04$ & 28 & 80 & 6 \\
$6-05$ & 35 & 90 & 4 \\
$12-06$ & 100 & 100 & 2 \\
\hline
\end{tabular}

a Approximate time obtained from extending the line to $[\eta]=0.01$.

Several well-defined copolymer samples with different segment lengths have been synthesized in quantitative yield with microphase separation morphology. Some of their physical and mechanical properties are shown as follows (Table XV):

In vitro degradation of several polymer films in deionized water was investigated for 70 days. The results revealed that the degradation of all block copolymer samples were better than that of PCL but slower than that of PLA as follows (Table XVI).

The rate of degradation varied with the segment length ratio PCL/PLA, i.e., increases with increasing PLA segment length. The time for complete degradation of block copolymer films at $50^{\circ} \mathrm{C}$ seems to be in the range of four months to about three years depending on caprolactone (CL)/lactide (LA) ratio.

In vitro release of norgestrel from the polymer matrix $(0.2-0.3 \mathrm{~mm}$ thickness) was observed for 20 days with the following results (Table XVII).

After a rapid decline in release amount during first four days, a relative sustained release rate is observed during the following days. The release behavior of the block copolymer also varied with the mole ratio of CL/LA. Increase of the length of PCL segments caused an increase of release rate of norgestrel.

Although the prepared diblock copolymers showed some advantages over the random copolymers especially when used as biodegradable drug release delivery materials to provide various controllable periods of biodegradation and drug release rates, we have synthesized and investigated further the ABA triblock copolymers with PCL and A and PLA as B. ${ }^{23}$ PLA in > AL-PLA-OR form was proved to be living for LA monomer but not for CL monomer which was ascribed to some steric hindrance between LA unit and CL monomer. We used ethylene oxide (EO) to extent the PLA chain in order to reduce the steric hindrance but the PEO chain is not truly 'living.' So we have to activate the $\left(-\mathrm{OCH}_{2} \mathrm{CH}_{2}\right)_{2-4} \mathrm{OH}$ end group with the modified Teyssie catalyst in which the three 2-ethylhexanate $(\mathrm{EHa})$ groups are inactive and only one i-PrO group is active, i.e.,

$$
\begin{aligned}
& \text { i-PrO-Al-OZnO-Al(OEHa })_{2} \\
& \text { OEHa }
\end{aligned}
$$

The active prepolymer and then the ABA triblock copolymer is formed through the following reactions:

$\left.\mathrm{PCL}-\mathrm{PLA}+\mathrm{OCH}_{2} \mathrm{CH}_{2}\right)_{2-4} \mathrm{OH}$

$$
+{ }_{\mathrm{i}-\mathrm{PrO}-\mathrm{Al}}<\mathrm{OEHaA}(\mathrm{OEHO}
$$

Polymer J., Vol. 17, No. 1, 1985 
Some Advances in Synthetic Biomedical Polymers

Table XVII. In vitro release of norgestrel from the polymer matrix

\begin{tabular}{ccccc}
\hline $\begin{array}{c}\text { Polymer } \\
\text { No. }\end{array}$ & $\mathrm{CL}$ & $\begin{array}{c}\text { Drug load } \\
\text { mol\% }\end{array}$ & $\begin{array}{c}\text { Released } \% \\
\text { in } 70 \text { days }\end{array}$ & $\frac{\begin{array}{c}\text { Relative sustained } \\
\text { released amount }\end{array}}{\mathrm{mg} \mathrm{day}^{-1} \mathrm{~cm}^{-2} \mathrm{film}^{\circ}}$ \\
\hline $12-03$ & 100 & 30.0 & 20.0 & $55-70$ \\
$12-05$ & 88 & 30.9 & 22.2 & $60-80$ \\
$12-04$ & 72 & 29.0 & 14.5 & $35-55$ \\
$12-06$ & 0 & 29.6 & 7.7 & $20-35$ \\
\hline
\end{tabular}

Table XVIII. Physical and mechanical properties of ABA copolymer

\begin{tabular}{|c|c|c|c|c|c|c|c|}
\hline Code & $\frac{\mathrm{CL} / \mathrm{LA}}{\mathrm{mol}}$ & $M_{n} \times 10^{-4}$ & PCL/PLA/PCL & $\frac{\mathrm{mp}}{{ }^{\circ} \mathrm{C}}$ & $\begin{array}{c}\begin{array}{c}\text { Tnesile } \\
\text { strength }\end{array} \\
\mathrm{kg} \mathrm{cm}^{-2}\end{array}$ & $\begin{array}{l}\text { Elongation } \\
\text { at break \% }\end{array}$ & $\frac{M_{w}}{M_{n}}$ \\
\hline $12-03$ & $100 / 0$ & 4.5 & & 63 & 273 & 133 & 1.12 \\
\hline $12-06$ & $0 / 100$ & 1.3 & & - & 220 & 250 & - \\
\hline $12-05$ & $88 / 12$ & 4.0 & $35000 / 5000 / 0$ & 65 & 229 & 100 & 1.09 \\
\hline $12-04$ & $72 / 28$ & 3.9 & $29000 / 10000 / 0$ & 64 & 220 & 380 & 1.14 \\
\hline 4-04 & $80 / 20$ & 3.9 & $24000 / 9000 / 6000$ & 66 & 230 & - & 1.28 \\
\hline $4-05$ & $75 / 25$ & 3.8 & $20000 / 11000 / 6000$ & 65 & 240 & 600 & 1.20 \\
\hline $4-06$ & $65 / 35$ & 4.3 & $21000 / 17000 / 5000$ & 65 & 240 & 500 & 1.26 \\
\hline
\end{tabular}

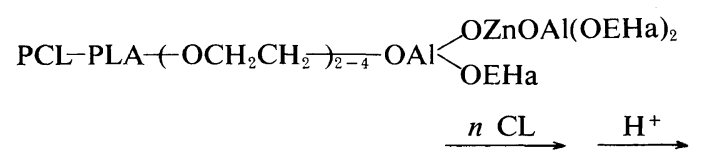

$\mathrm{PCL}-\mathrm{PLA}-\left(-\mathrm{OCH}_{2} \mathrm{CH}_{2}\right)_{2-4}\left[\mathrm{O}-\mathrm{O}-\mathrm{O}-\left(-\mathrm{CH}_{2}-\right)_{5}\right]_{n} \mathrm{OH}$ (PCL-PLA-PCL)

The copolymer samples with different compositions and segment lengths have been synthesized according to the above scheme. From molecular weight determination and GPC curves of these samples, it is proved that $\mathrm{ABA}$ triblock copolymers are actually formed with monodispersion of molecular weight. Some physical and mechanical properties of ABA block copolymers as compared with the $\mathrm{AB}$ diblock ones are shown as follows (Table XVIII).

It is interesting to find that the elongation at break of ABA block copolymer is usually higher than that of the $\mathrm{AB}$ block copolymers with similar CL/LA ratio. The 4-05 and 4-06 samples gave the high value of $500-600 \%$ without sacrifice of tensile strength. It is then considered that $\mathrm{ABA}$ triblock copolymers may serve as a new type of potential biomedical material with controlled biodegradability and sustained release properties. Moreover we have synthesized diblock copolymer of PCL-PGA and verified that polyglycolide (PGA) is also living for GA monomer itself but not for $\mathrm{CL}$ monomer. ${ }^{24}$ So the preparation of triblock copolymer of PCL-PGA-PCL through the above mentioned scheme is underway.

\section{REFERENCES}

1. D. L. Lyman, K. Knutson, B. McNeill, and K. Shibatani, Trans. Am. Soc. Artif. Int. Organs, 21, 49 (1975).

2. Y. Imai, Kobunshi (in Japanese), 21, 569 (1972).

3. T. Okano, K. Kataoka, Y. Sakurai, M. Shimada, T. Akaike, and T. Shinohara, Proceedings of the 3rd Meeting of the International Society of Artificial Organs, 1981.

4. A. Nakajima, presented at the 4th Annual Meeting of Japan Society for Biomaterials. November 27, 
1982.

5. Z. X. Huang and X. D. Feng, Kexue Tongbao, (Bull. Sci.), 5, 632 (1983).

6. F. L. Yang and X. D. Feng, Polym. Commun. (in Chinese), 4, 302 (1982)

7. N. Tian, L. S. Li, G. L. Zhang, and X. D. Feng, Polym. Commun. (in Chinese), 3, 161 (1983).

8. M. Szycher, V. Poirier, and J. Keiser, Trans. Am. Soc. Artif. Int. Organs, 23, 116 (1977).

9. V. Poirier in "Synthetic Biomedical Polymers," M. Szycher, Ed., Technomic, 106, 1980.

10. B. D. Halpern, O. Solomon, D. G. Chowhan, and W. Karo, NIH-NO 1-HV-6-1124 (1976).

11. Y. H. Sun, Ph. D. Thesis, Department of Chemistry, Peking University, China 1984.

12. Y. H. Sun, K: Y. Qiu, and X. D. Feng, Polym. Commun (in Chinese), 2, 81 (1983).

13. T. Matsuda and H. Iwata, Kobunshi Kako (in Japanese), 32, 353 (1983).

14. H. Y. Chen, B. Z. Xu, and X. D. Feng, J. Polym. Sci., Polym. Chem. Ed., 20, 547 (1982).

15. H. Y. Chen, B. Z. Xu, and X. D. Feng, "The proceeding of the Conference of the International Society of Artificial Organs on Hemoperfusion and Artificial Organs," Tiantsin held in 1983, in press.

16. A. Nakajima and H. Sato, Biopolymers, 11, 1345 (1972).

17. K. Kataoka, T. Akaike, Y. Sakurai, and T. Tsuruta, Makromol. Chem., 179, 1121 (1978).

18. L. Wang, Master Thesis submitted to Chemistry Department, Peking University, 1984.

19. F. M. Li, Z. W. Gu, and X. D. Feng, Polym. Commun. (China, in English), 1, 71 (1983).

20. Z. W. Gu, F. M. Li, and X. D. Feng, Biomater. Med. Dev. Art. Org. (U.S.A.), 11, (2/3), 211 (1983).

21. F. M. Li, Z. W. Gu, G. W. Li, and X. D. Feng, Preprints, Polymer Symposium, Polymer Division of Chinese Chemical Society, Hangzhou, China, 1983, p 136.

22. X. D. Feng, C. X. Song, and H. Y. Chen, J. Polym. Sci., Polym. Lett. Ed., 21, 593 (1983).

23. C. X. Song and X. D. Feng, Macromolecules, in press (1984).

24. Y. Zhang and X. D. Feng, unpublished work. 